\title{
FORMATION OF THE INFORMATION SUPPORT FOR THE ENTITIES OF MANAGEMENT BY THE DEVELOPMENT OF INNOVATION CLUSTERS
}

\author{
Olexandra Farat ${ }^{1}$, Mariana Bets ${ }^{2}$ \\ Lviv Polytechnic National University, Ukraine
}

\begin{abstract}
In a context of rapid innovative economic development in the world, a particular importance gets the issue of creation and development of highly effective, the structured field of information, where all people, who are interested in developing of business innovation, are the entities of communication. Availability of reporting mechanisms for interested people by country and getting feedback of information with the proposals of territorial authorities and economic entities for the realization of investment and innovative projects in regions should be considered as one of the main stages in the process of synchronizing innovation development in the Ukrainian economy. The purpose of the researches in the article was to identify the main components of the formation of the information support for entities of management by innovation clusters development. The authors resolved the following tasks to achieve the goal: the genesis of domestic legislation with development of the information society in Ukraine was considered; Ukraine's place in global rankings on development of information and communication technologies level during 2008-2016 was analysed, identification of information needs of participants in the process of creating and developing clusters was carried out, and communication strategy to stimulate the development of innovation clusters was developed. The genesis of the domestic legislation on the development of the information society in Ukraine demonstrated a lack of systematic approach to the organization and the process of integral development of the information society. These legislations are characterized more recommendatory, than functionally-structured content. In particular, they do not address clearly defined mechanisms for achieving objectives that were in line with the specific functional responsibilities on all levels of public administration. The analysis of Ukraine's global rankings on development of information and communication technologies level during 2008-2016, evidences a significant passivity of all the participants in Ukrainian economic life not only in a development processes and dissemination of information technology, also on the formation of structured arrangements of the information management of the main economic process, including the processes of creating and developing innovative cluster associations. An important prerequisite for the efficient development of information management's mechanisms for the economy in Ukraine is the identification of all actual information needs and connected entities of the business, research institutes, territorial authorities etc. The authors' identification of information needs of participants in the process of creating and developing clusters will assess the significance of effects of casters associations on the country's economy, in particular, the possibility of innovative development. The authors' strategies to stimulate the development of innovative clusters will help improve creating information and clusters development depending on the purpose and sources of its simulating.
\end{abstract}

Key words: innovative development, cluster business combinations, information support, information support system, entities of clusters development management.

JEL Classification: L10, O19, O32

\section{Introduction}

In a context of rapid innovative economic development in the world, a particular importance gets the issue of creation and development of highly effective, structured field of information, where all people, who are interested in developing of business innovation, are the entities of communication. Availability of reporting mechanisms for interested people by country and getting feedback of information with the proposals of territorial authorities and economic entities for the realization of investment

\footnotetext{
Corresponding author:

${ }^{1}$ Department of Enterprise and Ecological Examination of Goods, Lviv Polytechnic National University.

E-mail: farat_o@ukr.net

${ }^{2}$ Department of Enterprise and Ecological Examination of Goods, Lviv Polytechnic National University.

E-mail: becmtpeet@ukr.net
} 
and innovative projects in regions should be considered as one of the main stages in the process of synchronizing innovation development in the Ukrainian economy in accordance with the world realities.

Therefore, especially important is the issue of developing and harmonizing at the state level not only the mechanisms of direct and feedback between all participants in the innovation process (profile ministries, territorial authorities, independent economic entities and their associations), but also the legislative approval of the relevant methodology for evaluating the effectiveness of information state policy on stimulating the development of innovative business, in particular, cluster associations.

Nowadays, the issue of cluster paradigm development not only in the domestic economy but also in the global economic environment is of particular relevance, which leads to a steady increase in the number of researchers who pay their attention to clusters. Among the domestic scientists who deal with research on the possibilities of cluster development and their impact on the growth of the economic competitiveness are: Z.S. Varnalii, L.I. Fedulova, I.O. Degtyareva, O.I. Zhabynets, Yu.V. Fedotova, and others. As for foreign scientists, the theme of clusters was especially explored by Michael Porter, G. Lindquist, S. Rozenfeld, E. Gleiser and others.

The key attention in the works of these scholars was given to the study of the essence of the notion "cluster" as a subject of market relations and its impact on the potential growth of the economy's competitiveness in particular by its achieving "synergy and scale effects." Concerning the works devoted to the complex study of the information interaction between the entities of the cluster development management, such studies are rather superficial, especially from the side of domestic scientists.

To achieve the goal, the authors solved the following tasks: the genesis of domestic legislation on information society development in Ukraine was considered, Ukraine's place in global ranking of the level of information and communication technologies development during 2008-2016 was analysed, identification of the information needs of participants in the process of creating and developing of clusters was carried out, and a package of information support strategies to stimulate the development of innovative clusters was developed.

\section{The genesis of domestic legislation on the information society development in Ukraine}

The process of creation and development of the information society in Ukraine began in 1998. A series of documents aimed at the formation of legal, organizational, scientific and technical, economic, financial, methodological, and humanitarian prerequisites for the development of informatisation was adopted.
They are the following:

1. The Law of Ukraine "On the National Program of Informatisation". According to this Law, the National Informatisation Program aims at the system developing of national information resources, increasing the efficiency of domestic production on the basis of a widespread use of information technologies, formation and support of the market for information products and services, etc.

2. Activities Program of the Cabinet of Ministers of Ukraine "Overcoming the Impact of the World Financial and Economic Crisis and Sustainable Development", which envisaged the measures necessary to overcome the consequences of the global financial and economic crisis in the context of the development of the information society in Ukraine.

3. Decree of the President of Ukraine No. 47/2017 "On Decision of the National Security and Defence Council of Ukraine dated December 29, 2016 "On the Doctrine of Information Security of Ukraine”.

The considered genesis of the domestic legislation on the development of the information society in Ukraine shows the absence of a systematic approach to the organization and implementation of the comprehensive development of the information society process in Ukraine. These legislative acts are characterized by more recommendatory than functionally-structured content. In particular, there aren't considered well-defined mechanisms for achieving the objectives that would be consistent with specific functional responsibilities at all levels of government.

\section{Analysis of Ukraine's place in the global ranking of the level of information and communication technologies development}

The processes of information society development in modern Ukraine should be considered as one of the stages of the most qualitative reform of the national economy, which is intended to improve the paths of the key economic processes, such as: investment attraction, development infrastructure, deepening of international financial and economic cooperation, development of alternative paradigms of the economy functioning (ecologically oriented economy, cluster economy, etc.).

Recent virus attacks by the modified version of the WannaCry virus - "cryptolocker" (May 2017 July 2017) have shown a significant weakness of information security for domestic enterprises and organizations, which has led to a deeper concentration of state attention on information security of enterprises and organizations. For the realization of this task, it is necessary to establish clearly the mechanisms of information interaction between business entities, nonprofit organizations, state institutions on the exchange of various information products, including databases of signature of viruses. 
This problem is reflected in the international ratings of Ukraine. In particular, according to the published Global Information Technology Development Report-2016 (The Global Information Technology Report), Ukraine has ranked 64th out of 139 countries in terms of the information and communication technologies development in 2016.

More details about the dynamics of this indicator for 2008-2016 are presented in Table 1 (website of the Economic Discussion Club, 2016).

Table 1

Ukraine's place in the global ranking of the level of information and communication technologies development during 2008-2016

\begin{tabular}{|c|c|c|c|}
\hline Years & $\begin{array}{c}\text { Place in } \\
\text { ranking }\end{array}$ & $\begin{array}{c}\text { Total number of } \\
\text { evaluated countries }\end{array}$ & $\begin{array}{c}\text { Position change relative } \\
\text { to the previous year }(+/-)\end{array}$ \\
\hline 2008 & 70 & 122 & - \\
\hline 2009 & 62 & 134 & -8 \\
\hline 2010 & 82 & 133 & +20 \\
\hline 2011 & 90 & 138 & +8 \\
\hline 2012 & 75 & 142 & -15 \\
\hline 2013 & 73 & 144 & -2 \\
\hline 2014 & 81 & 148 & +8 \\
\hline 2015 & 71 & 143 & -10 \\
\hline 2016 & 64 & 139 & -7 \\
\hline
\end{tabular}

According to the data of Table 1, during the reviewed period, Ukraine has taken the mediated positions in this ranking, out of 9 positions in five, there was a decline in the level of information and communication technologies development according to the surveyed indicators relative to the previous year, and only in 2010, 2011, and 2014, an increase in the level of development of informational-communication technologies was observed.

The data in Table 1 indicate a significant passivity of all participants in the economic life of Ukraine not only in the processes of development and dissemination of information technologies, but also in the formation of structured mechanisms for the systematic information provision of key economic processes (processes associated with the creation and development of innovative cluster associations).

\section{Identification of information needs of participants in the process of creating and developing clusters}

One of the important prerequisites for the effective development of information support mechanisms in the development of the Ukrainian economy is the clear identification of all relevant information needs and related entities, in particular, business, research institutions, territorial authorities, etc. The experience of the advanced countries (The US, Germany, Sweden) shows that precisely progressive information policy is one of the key elements of the development of highperformance innovative business in the state.

In essence, the information need of an enterprise is the need for obtaining certain information, which manifests itself then, when a target for a particular consumer arises, the achievement of which is impossible without external information intervention (Witer, 2011).

Exploring the peculiarities of the process of information provision of the cluster development management entities, we will identify them in the structure of the modern economy.

Thus, according to (Dehtiarova, 2011), key players of the clusters development issues are:

- vertically or horizontally connected companies, business associations, providers of specialized services (marketing, logistics, financial) that in aggregate form the private sector of the domestic economy;

- profile ministries, state agencies, the other public authorities of local, regional, and national levels;

- educational and research institutions, namely: research institutes, universities, vocational training centres.

All of them form the so-called "triple spiral", the key role of the entities of the innovative clusters development management belongs to the government sector (profile ministries, state agencies, state authorities of local, regional and national levels), since they have the most complete authority, have more access to state financial resources, and can have a significant impact on the economic and legal environment in the state.

Identification of the information needs of participants in the process of creating and developing clusters is highlighted in Table 2.

The important criteria to assess the feasibility of information dissemination on development opportunities and nurturing of clusters are that they qualify certain requirements. These claims include:

- Municipal sector-based compatibility - provides conformity distributed in the information region for the possibility of creating and long-term development of clusters and their sectoral complexes.

- Trend orientation - provides an orientation of the information dissemination on the world tendencies of economic, social, and environmental development of economic entities in order to facilitate their full competitiveness in the global economic area.

- Programme coherence - provides the greatest possible to meet the needs of economic entities in access to resources offered by domestic, overseas, and joint development programs.

The importance should be given to stimulating measures. The world practice shows that role of government in a process of organization stimulating measures are very considerable and can be manifested in different forms (target programmes, government grants, public-private partnership projects etc.) In particular, the most used stimulating measures that provide an 
Table 2

Identification of information needs of participants in the process of creating and developing clusters

\begin{tabular}{|l|l|l|}
\hline $\begin{array}{l}\text { The entity of development } \\
\text { administration of clusters }\end{array}$ & \multicolumn{1}{|c|}{ The information need } & \multicolumn{1}{c|}{ The content of needed information } \\
\hline Business & $\begin{array}{l}\text { 1. The requirement for identifying } \\
\text { available sources financial and material } \\
\text { measures } \\
\text { 2. Finding ways to ensure strategic } \\
\text { development } \\
\text { 3. Need to find ways of legal optimization } \\
\text { the tax burden }\end{array}$ & $\begin{array}{l}\text { 1. Access to information for preferential loans scheme, the } \\
\text { potential of marketing etc. } \\
\text { 2. Access to information on the development opportunities } \\
\text { through the amalgamation, cooperation with foreign partners etc. } \\
\text { 3. Access to information for possible tax preferences conditional } \\
\text { on the implementation of the systemic innovation, development } \\
\text { of programmes for social responsibility etc. }\end{array}$ \\
\hline $\begin{array}{l}\text { The public authorities } \\
\text { of local, regional, and } \\
\text { national elections }\end{array}$ & $\begin{array}{l}\text { 1. Seeking for potential participants able to } \\
\text { perfectly develop the economy } \\
\text { 2. Maximum possible utilization of certain } \\
\text { programmes for strategic development }\end{array}$ & $\begin{array}{l}\text { 1. Information on economic entities, research institutes, which } \\
\text { are of sufficient human, financial, material capital, and willing to } \\
\text { system of innovation development }\end{array}$ \\
\hline $\begin{array}{l}\text { Education and research } \\
\text { institutions }\end{array}$ & $\begin{array}{l}\text { 1. Need for sources in the available } \\
\text { production and developing potential } \\
\text { intellectual capital. } \\
\text { 2. Sourcing of diversification their funding. }\end{array}$ & $\begin{array}{l}\text { 1. Information about opportunities of its capacity of research } \\
\text { institutions within the government programs, on request of the } \\
\text { individual enterprise or groups. }\end{array}$ \\
\hline
\end{tabular}

opportunity to inform the potential participants, to unite them into clusters, and to perform other actions, are the following (Zhabynets, 2014):

- Information platforms, platforms to search for partners, cooperation (for example, the regular distribution of marketing information and information connected to a technology development, events under the networks, work groups);

- Supporting start-ups and innovations (for example, identifying interlocutors and sources of financing to support the common innovative/research projects that incubators initiate and thrusters, initiatives to strengthen linkages between science and industry);

- Initiation of specialized of infrastructure projects (for example, the incubator concept, scientific and industrial parks);
- Cluster marketing (awareness-raising of cluster activities and its members at the regional, national, and international levels, for example, website, bulletin, cluster's atlas).

\section{Strategies to stimulate the development of innovative clusters}

Information management on the creation and stimulation of clusters must be ensured by clearly defined tools of strategic vision that is, having a package of policies of information management to stimulate the development of innovative clusters in Ukraine. Examples of such policy packages are given in Table 3.

The proposed strategies of information support to stimulate the development of innovative clusters must

Table 3

Information support strategies to stimulate the development of innovative clusters

\begin{tabular}{|c|c|c|}
\hline $\begin{array}{l}\text { Source } \\
\text { of initial stimulation }\end{array}$ & Development of the existing innovative cluster & Establishment of a new innovative cluster \\
\hline $\begin{array}{l}\text { Initial stimulation from } \\
\text { the government }\end{array}$ & $\begin{array}{l}\text { 1. The synchronous strategy of updating the } \\
\text { functioning (transition to the government } \\
\text { control for the production of new technologies or } \\
\text { modernized product, in accordance with current } \\
\text { requirements of the world market) }\end{array}$ & $\begin{array}{l}\text { 4. The vertical strategy of association for integration } \\
\text { (creation of a cluster happens for governmental initiatives, } \\
\text { by combining state-owned enterprises with the possible } \\
\text { contribution of contractual arrangements of the private } \\
\text { entities of management, by its information about possible } \\
\text { gains from participating in territorial clustering) }\end{array}$ \\
\hline $\begin{array}{l}\text { Initial stimulation from } \\
\text { the side of economic } \\
\text { entities }\end{array}$ & $\begin{array}{l}\text { 2. The strategy of smooth innovative development } \\
\text { (provides for the implementation to inform of } \\
\text { the cluster's members of relevant government } \\
\text { institutions the need to give concessional loans, } \\
\text { relevant authorizations, which given the current } \\
\text { trends of industrial development systemically } \\
\text { implementing in their progressive of innovative } \\
\text { solutions and gives a clear justification of } \\
\text { usefulness of such action }\end{array}$ & $\begin{array}{l}\text { 5. The horizontal strategy of integration groupings (cluster } \\
\text { creating happens by an independent initiative of economic } \\
\text { entities, using reverse channels of communication with the } \\
\text { public authorities after relevant negotiation define the real } \\
\text { economically desirable to create such a cluster (clusters), } \\
\text { also mechanisms of government support for its (their) } \\
\text { development }\end{array}$ \\
\hline $\begin{array}{l}\text { Combined initial } \\
\text { stimulation }\end{array}$ & $\begin{array}{l}\text { 3. Transformation strategy (full organizational } \\
\text { cluster transformation: replacement of } \\
\text { central business, diversification of the cluster } \\
\text { by separating it into smaller clustering, the } \\
\text { establishment of cross-border clustering) }\end{array}$ & $\begin{array}{l}\text { 6. A common strategy of integration groupings (a cluster } \\
\text { (both internal and transboundary) is established by a } \\
\text { joint of initiative public authorities' initiatives and local } \\
\text { companies, through their participation in the competition } \\
\text { in the target government or regional programmes) }\end{array}$ \\
\hline
\end{tabular}


suffer an appropriate legal and regulatory basis, that is, a clearly regulated in the proper industry legislative instruments (regional development strategies, sectoral development programmes, etc.) in order to ensure all specific the industries concerned of the national economy in Ukraine. A certain strategic vision to stimulate the development of innovative clusters will improve the information establishment and development of clusters, depending on the purpose and source of its initial stimulation.

\section{Conclusion}

The objectives were completely solved by the authors.

The genesis of the domestic legislation on the development of the information society in Ukraine demonstrated a lack of systematic approach to the organization and the process of integral development of the information society. These legislations are characterized more recommendatory, than functionallystructured content.
The analysis of Ukraine's global rankings on development of information and communication technologies level during 2008-2016, evidences a significant passivity of all the participants in Ukrainian economic life not only in a development processes and dissemination of information technology, also on the formation of structured arrangements of the information management the main economic process, including the processes of creating and developing innovative cluster associations.

The authors' identification of information needs of participants in the process of creating and developing clusters will assess the significance of effects of casters associations on the country's economy, in particular, the possibility of innovative development.

The authors' strategies to stimulate the development of innovative clusters will help improve creating information and clusters development depending on the purpose and sources of its simulating.

\section{References:}

Dehtiarova I.O. (2011) Naukovi ta praktychni aspekty zastosuvannia klasternoho pidkhodu v upravlinni konkurentospromozhnistiu rehioniv Ukrainy [Scientific and practical aspects of application of the cluster approach in the management of the competitiveness of the regions of Ukraine]. Derzhavne upravlinnia: teoriia ta praktyka [Public administration: theory and practice], no. 3. Retrieved from: http://www.academy.gov.ua/ej/ej13/txts/ Degtyaryova.pdf

Fedotova Yu.V. (2015) Dosvid ta perspektyvy funktsionuvannia klasternykh struktur v ekonomitsi Ukrainy [Experience and prospects of functioning of cluster structures in the economy of Ukraine]. Efektyvna ekonomika [Effective economics] (electronic journal), no. 4. Retrieved from: http://www.economy.nayka.com. $\mathrm{ua} /$ op $=1 \& \mathrm{z}=3961$

Mazii N.H. (2011) Pryntsypy ta mekhanizmy derzhavnoho rehuliuvannia rozvytku pidpryiemnytstva [Principles and mechanisms of state regulation of enterprise development]. Demokratychne vriaduvannia [Democratic Governance], vol. 8. Retrieved from: http://nbuv.gov.ua/UJRN/DeVr_2011_8_8

Sait ekonomichnoho dyskusiinoho klubu [Website of the Economic Discussion Club]. Retrieved from: http://edclub.com.ua/analityka/reytyngovi-ocinky-ukrayiny-za-indeksom-merezhevoyi-gotovnosti-2016

Sait Nimetskoi konsultatyvnoi hrupy [Website of the German Advisory Group. Retrieved from: https://www.beratergruppe-ukraine.de/wordpress/wp-content/uploads/2016/01/PP_04_2015_ukr.pdf

Voitko S.V. (2012) Upravlinnia rozvytkom naukomistkykh pidpryiemstv [Management of the $\overline{\text { development of }}$ high-tech enterprises]. - Kiev: NTUU «KPI», pp. 280.

Zhabynets O. (2014) Realizatsiia v Ukraini klasternykh initsiatyv za uchastiu strakhovykh kompanii: stan, dosvid, perspektyvy [Implementation of cluster initiatives in Ukraine with the participation of insurance companies: state, experience, prospects. Journal of European Economics]. Zhurnal yevropeiskoi ekonomiky [Journal of the European economy], vol. 13, no. 2, pp. 205-213. 